\title{
Effect of dietary amino acid composition from proteins alternative to fishmeal on the growth of juveniles of the common snook, Centropomus undecimalis
}

\author{
Cristiane Freire Silvão ${ }^{1}$, Alberto Jorge Pinto Nunes ${ }^{2 *}$ \\ ${ }^{1}$ Instituto Federal de Educação, Ciência e Tecnologia da Bahia, Salvador, BA, Brazil \\ 2 Universidade Federal do Ceará, Instituto de Ciências do Mar, Fortaleza, CE, Brazil.
}

ABSTRACT - This study investigated the effect of dietary amino acid composition from proteins alternative to fishmeal on the growth performance of the common snook, Centropomus undecimalis. Fish of $10.79 \pm 0.71 \mathrm{~g}(\mathrm{n}=150)$ were stocked in 15 shaded outdoor tanks of $1 \mathrm{~m}^{3}$. The basal diet contained $643.4 \mathrm{~g} \mathrm{~kg}^{-1}$ salmon byproduct meal (SML) and $200.0 \mathrm{~g} \mathrm{~kg}^{-1}$ soy protein concentrate (SPC). Two other diets replaced 39 and $29 \%$ of the SML with poultry byproduct meal (PBM, $\left.170.1 \mathrm{~g} \mathrm{~kg}^{-1}\right)$ and SPC (334.9 $\left.\mathrm{g} \mathrm{kg}^{-1}\right)$, respectively. Fish were fed twice daily for 84 days under $32 \pm 1 \mathrm{~g} \mathrm{~L}^{-1}$ water salinity and $27.3 \pm 0.9^{\circ} \mathrm{C}$ temperature. Final survival (99.5 $\pm 2.6 \%$ ) was unaffected by dietary treatment. Snook grew slower $\left(0.24 \pm 0.03\right.$ and $\left.0.27 \pm 0.04 \mathrm{vs}_{0.35 \pm 0.06 \mathrm{~g} \text { day }}{ }^{-1}\right)$ and achieved the lowest body weight $(31.1 \pm 6.62$ and $33.3 \pm 10.20 \mathrm{vs} 40.4 \pm 13.18 \mathrm{~g})$ and the highest feed conversion ratio $(3.69 \pm 0.29$ and $3.11 \pm 0.51$ vs $2.33 \pm 0.34$ ) when fed SPC and basal diets compared with PBM, respectively. Retention of dietary crude protein varied from 36 to $38 \%$ for fish fed the basal and SPC diets, but exceeded 51\% in fish fed PBM. Results indicate a greater ability of the common snook to gain weight and increase retention of nutrients when dietary protein is of terrestrial animal origin. Dietary protein from PBM yields a more balanced dietary amino acid composition relative to fish muscle, but possibly in excess of the species requirements.

Key Words: amino acid, fishmeal, fish nutrition, nutritional requirement

\section{Introduction}

Marine fish farming is one of the fastest growing aquaculture sectors, in terms of value, harvested volumes, and number of emerging farmed species. From 2000 to 2013, global production of farm-raised marine fish grew at an annual rate of $6.9 \%$, from 0.97 to 2.28 million t, respectively. In 2013 , the industry generated USD 9.5 billion or $6.1 \%$ of the total aquaculture revenue (FAO, 2014). Several marine fish are reared commercially, including the Asian seabass (Lates calcarifer), cobia (Rachycentron canadum), groupers (Epinephelus spp), snappers (Lutjanus spp), pompanos (Trachinotus spp), yellowtails, and amberjacks (Seriola spp).

In the Americas, the common snook, Centropomus undecimalis, is a marine fish of commercial interest. The

Received: January 4, 2016

Accepted: March 25, 2017

*Corresponding author: alberto.nunes@ufc.br

http://dx.doi.org/10.1590/S1806-92902017000700003

How to cite: Silvão, C. F. and Nunes, A. J. P. 2017. Effect of dietary amino acid composition from proteins alternative to fishmeal on the growth of juveniles of the common snook, Centropomus undecimalis. Revista Brasileira de Zootecnia 46(7):569-575

Copyright (C) 2017 Sociedade Brasileira de Zootecnia. This is an Open Access article distributed under the terms of the Creative Commons Attribution License (http://creativecommons.org/licenses/by/4.0/), which permits unrestricted use, distribution, and reproduction in any medium, provided the original work is properly cited. species attracts high prices as recreational and commercial fish because of its highly valued fillet (Rhody et al., 2010; Muller and Taylor, 2012). The common snook can tolerate a wide range of salinities (Pérez-Pinzón and Lutz, 1991; Tucker and Kennedy, 2003; Gracia-López et al., 2006) and preys on small fish, shrimp, and crabs in its natural habitat (Rivas, 1986; Tsuzuki et al., 2007; Alvarez-Lajonchère and Ibarra-Castro et al., 2013). Broodstock can mature and spawn in captivity (Neidig et al., 2000; Sánchez-Zamora et al., 2002; Ferraz and Cerqueira, 2010; Ibarra-Castro et al., 2011; Rhody et al., 2014; Contreras-García et al., 2015) and thus, pilot-scale mass production of fries has been achieved (Ibarra-Castro et al., 2011).

Compared with other emerging farm-raised warmwater marine fish, such as the Asian seabass (Lates calcarifer; Boonyaratpalin, 1997; Glencross, 2006), and cobia (Rachycentron canadum; Salze et al., 2010), limited information is available on feeding and nutrition of the common snook. Attempts to raise the species in captivity have relied on diets of fresh food (Tucker, 1987; Zarza-Meza et al., 2006a,b) or on feeds formulated for carnivorous freshwater fish (Gracia-López et al., 2003) or for other warm-water marine species (Soligo et al., 2011). Tucker (1987) found an improved growth when juveniles of the common snook were fed diets with $500 \mathrm{~g} \mathrm{~kg}^{-1}$ of $\mathrm{CP}$ and $130 \mathrm{~g} \mathrm{~kg}^{-1}$ fat. The present study investigated the 
effect of the dietary amino acid composition from protein sources alternative to fishmeal on the growth performance of juveniles of the common snook.

\section{Material and Methods}

Hatchery-produced fries of the common snook, $C$. undecimalis, were purchased from a commercial hatchery (Danúbio Piscicultura Ltda., Blumenau, SC, Brazil) and transported by air cargo to the laboratory rearing facilities in Eusébio, CE, Brazil. Animals $(\mathrm{n}=1,500)$ were equally distributed at a maximum biomass of $30 \mathrm{~g} \mathrm{~L}^{-1}$ into four transparent double plastic bags containing seawater $(\mathrm{pH}$, 6.6; temperature, $27.5^{\circ} \mathrm{C}$; and salinity, $20 \mathrm{~g} \mathrm{~L}^{-1}$ ) enriched with pure oxygen, which were accommodated in two Styrofoam boxes. Transportation lasted $14 \mathrm{~h}$ and one dead fish was noted on arrival at the experimental site.

Initially, fish were stocked in four indoor tanks of $0.5 \mathrm{~m}^{3}$ for acclimation over two days in water salinity of $36 \mathrm{~g} \mathrm{~L}^{-1}$. Fish were then graded by size and distributed into 50 indoor tanks each of $0.5 \mathrm{~m}^{3}$, under continuous aeration and water filtration. At this time, fish weighed $1.71 \pm 0.62 \mathrm{~g}(\mathrm{n}=29)$. Fingerlings were reared under similar conditions for 54 days until reaching an average body weight of $11.21 \pm 2.55 \mathrm{~g}(\mathrm{n}=50)$.

Following acclimation, juveniles were graded by size, weighed individually $(10.79 \pm 0.71 \mathrm{~g} ; \mathrm{n}=150 ; \mathrm{CV}=6.6 \%)$, and immediately transferred to 15 outdoor tanks of $1 \mathrm{~m}^{3}$ (1.02 $\mathrm{m}^{2}$ bottom surface area by $0.74 \mathrm{~m}$ height) at $10 \mathrm{fish}$ $\mathrm{m}^{-3}$. During the rearing period, tanks were covered with a perforated lid and sheltered from the sunlight using a dark net with 70\% shading (sombrite 1007 PTO 70\%, Equipesca Equipamentos de Pesca Ltda., Nova Odessa, SP, Brazil). Tanks operated with clear water under a closed regime, with continuous water recirculation, filtration, and aeration. Water filtration was carried out using a $240-\mathrm{kg}$ sand filter and a cartridge filter with seven $75 \mu \mathrm{m}$ filter vessels (model XL-234, FSI Sul Americana Ind. Com. e Serviços Ltda., Taubaté, SP, Brazil).

To avoid any build-up of organic matter on the bottom surface of the tank, feed remains and feces were siphoned twice a week. Water salinity, $\mathrm{pH}$, temperature, and dissolved oxygen were monitored at $09.00 \mathrm{~h}$ daily in each rearing tank. Readings of water alkalinity, nitrite, nitrate, and total ammonia nitrogen were conducted with a visible spectrophotometer (DR-2800 Spectrophotometer, Hach Company, Loveland, USA). Water was sampled from a randomly selected tank for each dietary treatment, on the 22nd, 52nd, and 86th days.

During the acclimation period, fish were fed a diet containing $510 \mathrm{~g} \mathrm{~kg}^{-1}$ of crude protein and $120 \mathrm{~g} \mathrm{~kg}^{-1}$ of fat (as is basis), according to recommendations made for the common snook, C. undecimalis (Tucker, 1987), and the Asian seabass, L. calcarifer (Boonyaratpalin, 1997; Glencross, 2006). This diet was composed of (as fed basis) salmon byproduct meal $\left(590.0 \mathrm{~g} \mathrm{~kg}^{-1}\right)$, soy protein concentrate $\left(139.3 \mathrm{~g} \mathrm{~kg}^{-1}\right)$, wheat flour $\left(120.0 \mathrm{~g} \mathrm{~kg}^{-1}\right)$, krill meal $\left(50.0 \mathrm{~g} \mathrm{~kg}^{-1}\right)$, salmon oil $\left(33.9 \mathrm{~g} \mathrm{~kg}^{-1}\right)$, vitamin-mineral premix $\left(20.0 \mathrm{~g} \mathrm{~kg}^{-1}\right)$, soybean lecithin $\left(15.0 \mathrm{~g} \mathrm{~kg}^{-1}\right)$, DLmethionine $\left(10.9 \mathrm{~g} \mathrm{~kg}^{-1}\right)$, L-lysine $\mathrm{HCl}\left(8.0 \mathrm{~g} \mathrm{~kg}^{-1}\right)$, dicalcium phosphate $\left(5.6 \mathrm{~g} \mathrm{~kg}^{-1}\right)$, synthetic binder $\left(5.0 \mathrm{~g} \mathrm{~kg}^{-1}\right)$, and ascorbic acid monophosphate $\left(2.3 \mathrm{~g} \mathrm{~kg}^{-1}\right)$.

For the experimental rearing period, three diets were formulated to be isonitrogeneous, isolipidic, and isoenergetic (Table 1). A basal diet was first designed to

Table 1 - Ingredient and proximate composition of experimental diets

\begin{tabular}{|c|c|c|c|}
\hline \multirow[t]{2}{*}{ Ingredient } & \multicolumn{3}{|c|}{$\begin{array}{c}\text { Diets/inclusion } \\
\left(\mathrm{g} \mathrm{kg}^{-1} \text { of the diet, as is basis) }\right.\end{array}$} \\
\hline & Basal & Poultry & $\mathrm{SPC}$ \\
\hline Salmon byproduct meal ${ }^{1}$ & 643.4 & 464.2 & 499.6 \\
\hline Soy protein concentrate $(\mathrm{SPC})^{2}$ & 200.0 & 200.0 & 334.9 \\
\hline Poultry byproduct meal ${ }^{3}$ & 0.0 & 170.1 & 0.0 \\
\hline Wheat flour ${ }^{4}$ & 50.0 & 71.4 & 45.2 \\
\hline Salmon oil & 35.7 & 23.5 & 49.5 \\
\hline Others $^{5}$ & 70.9 & 70.9 & 70.9 \\
\hline \multicolumn{4}{|c|}{ Proximate composition ( $\mathrm{g} \mathrm{kg}^{-1}$ of the diet, as is basis) } \\
\hline Dry matter & 886.4 & 886.1 & 932.3 \\
\hline Crude protein & 521.3 & 517.3 & 528.8 \\
\hline Fat & 110.4 & 106.4 & 119.5 \\
\hline Crude fiber & 10.9 & 14.1 & 15.2 \\
\hline Ash & 130.8 & 119.7 & 121.0 \\
\hline Nitrogen-free extract ${ }^{6}$ & 226.6 & 242.5 & 215.5 \\
\hline Gross energy $\left(\mathrm{MJ} \mathrm{kg}^{-1}\right)^{7}$ & 19.2 & 19.2 & 19.5 \\
\hline
\end{tabular}

${ }^{1}$ Pesquera Pacific Star S.A. (Puerto Montt, Chile): $612.6 \mathrm{~g} \mathrm{~kg}^{-1}$ crude protein (CP); $100.1 \mathrm{~g} \mathrm{~kg}^{-1}$ fat; $148.5 \mathrm{~g} \mathrm{~kg}^{-1}$ ash; $0.9 \mathrm{~g} \mathrm{~kg}^{-1}$ crude fiber (CF); $94.7 \mathrm{~g} \mathrm{~kg}^{-1}$ moisture.

${ }^{2}$ Sementes Selecta S.A. (Goiânia, Brazil): $626.3 \mathrm{~g} \mathrm{~kg}^{-1} \mathrm{CP} ; 7.7 \mathrm{~g} \mathrm{~kg}^{-1}$ of fat; $42.3 \mathrm{~g} \mathrm{~kg}^{-1}$ ash; $43.3 \mathrm{~g} \mathrm{~kg}^{-1} \mathrm{CF} ; 82.2 \mathrm{~g} \mathrm{~kg}^{-1}$ moisture.

${ }^{3}$ Courtesy of InVivo Nutrição e Saúde Animal Ltda. (Paulínia, Brazil): $605.3 \mathrm{~g} \mathrm{~kg}^{-1} \mathrm{CP}$ $173.4 \mathrm{~g} \mathrm{~kg}^{-1}$ fat; $7.6 \mathrm{~g} \mathrm{~kg}^{-1}$ ash; $7.6 \mathrm{~g} \mathrm{~kg}^{-1} \mathrm{CF} ; 72.0 \mathrm{~g} \mathrm{~kg}^{-1}$ moisture.

${ }^{4}$ Farinha de trigo Rosa Branca. Moinhos Cruzeiro do Sul S/A (Olinda, Brazil): $134.1 \mathrm{~g} \mathrm{~kg}^{-1} \mathrm{CP} ; 21.7 \mathrm{~g} \mathrm{~kg}^{-1}$ fat; $12.4 \mathrm{~g} \mathrm{~kg}^{-1}$ ash; $7.4 \mathrm{~g} \mathrm{~kg}^{-1} \mathrm{CF} ; 110.4 \mathrm{~g} \mathrm{~kg}^{-1}$ moisture.

5 Others included: $20.0 \mathrm{~g} \mathrm{~kg}^{-1}$ of vitamin-mineral premix ${ }^{8} ; 20.0 \mathrm{~g} \mathrm{~kg}^{-1}$ of Krill meal'; $15.0 \mathrm{~g} \mathrm{~kg}^{-1}$ of soy lecithin; $10 \mathrm{~g} \mathrm{~kg}^{-1}$ of dicalcium phosphate ${ }^{10} ; 5.0 \mathrm{~g} \mathrm{~kg}^{-1}$ of synthetic binder ${ }^{11}$; and $0.9 \mathrm{~g} \mathrm{~kg}^{-1}$ of ascorbic acid polyphosphate ${ }^{12}$.

${ }^{6}$ Calculated by difference $(1,000$ - crude protein - fat - crude fiber - ash)

${ }^{7}$ Calculated using an energy value of protein, fat, and carbohydrate of $5.64 \mathrm{kcal} / \mathrm{g}$, $9.44 \mathrm{kcal} / \mathrm{g}$, and $4.11 \mathrm{kcal} / \mathrm{g}$, respectively.

${ }^{8}$ Rovimix Camarão Extensivo, DSM Produtos Nutricionais Brasil Ltda. (São Paulo, Brazil). Guaranteed levels per kg of product: vitamin A, 1,000,000 IU; vitamin D3, 300,000 IU; vitamin E, 15,000 IU; vitamin K3, $300.0 \mathrm{mg}$; vitamin B1, 3,000.0 mg; vitamin B2, 2,500.0 mg; vitamin B6, 3,500.0 mg; vitamin B12, $6.0 \mathrm{mg}$; nicotinic acid, 10,000.0 mg; pantothenic acid, 5,000.0 mg; biotin, $100.0 \mathrm{mg}$; folic acid, $800.0 \mathrm{mg}$; vitamin C, 25,000.0 mg; choline, 40,000.0 mg; inositol, 20,000.0 mg; iron 2,000.0 mg; copper, $3,500.0 \mathrm{mg}$; chelated copper, $1,500,0 \mathrm{mg}$; zinc, $10,500.0 \mathrm{mg}$; chelated zinc, 4,500.0 mg; manganese, 4,000.0 mg; selenium, $15.0 \mathrm{mg}$; chelated selenium, $15.0 \mathrm{mg}$; iodine, $150.0 \mathrm{mg}$; cobalt, $30.0 \mathrm{mg}$; chromium $80.0 \mathrm{mg}$; filler, $1,000.0 \mathrm{~g}$.

${ }^{9}$ Qrill'TM meal, Aker Biomarine ASA (Oslo, Norway): $593.0 \mathrm{~g} \mathrm{~kg}^{-1} \mathrm{CP} ; 203.0 \mathrm{~g} \mathrm{~kg}^{-1}$ fat; $123.0 \mathrm{~g} \mathrm{~kg}^{-1}$ ash; $203.0 \mathrm{~g} \mathrm{~kg}^{-1} \mathrm{CF} ; 62.0 \mathrm{~g} \mathrm{~kg}^{-1}$ moisture.

${ }^{10}$ Serrana Foscálcio20. Bunge Fertlizantes S/A. (Cubatão, Brazil): $205 \mathrm{~g} \mathrm{~kg}^{-1}$ calcium, $202 \mathrm{~g} \mathrm{~kg}^{-1}$ total phosphorus, $19.1 \%$ available phosphorus.

${ }^{11}$ Nutri-Bind Aqua Veg Dry, Nutri-Ad International NV (Dendermonde, Belgium). Synthetic pellet binder consisting of calcium lignosulfonate $(94.00 \%)$ and guar gum (6.00\%).

${ }^{12}$ Rovimix Stay-C $\mathrm{C}^{\circledR} 35 \%$, L-ascorbic acid 2-monophosphate. DSM Produtos Nutricionais Brasil Ltda. (São Paulo, Brazil). 
contain $520.0 \mathrm{~g} \mathrm{~kg}^{-1}$ of crude protein (as fed basis) with salmon byproduct meal (643.4 $\mathrm{g} \mathrm{kg}^{-1}$, as fed basis) and soy protein concentrate (SPC, $200.0 \mathrm{~g} \mathrm{~kg}^{-1}$ ) as the main protein sources. From this diet, two other diets were formulated to replace 39 and $29 \%$, respectively, of the salmon byproduct meal with two alternative proteins: poultry byproduct meal $\left(170.1 \mathrm{~g} \mathrm{~kg}^{-1}\right)$ and SPC $\left(334.9 \mathrm{~g} \mathrm{~kg}^{-1}\right)$.

Because of a general lack of information on the nutrient requirements of Centropomus spp, the dietary essential amino acid (EAA) profile approximated that of a freeze-dried muscle sample obtained from a wild-caught adult $C$. undecimalis (4 $\mathrm{kg}$ body weight). This formulation approach was in accordance with the work of Portz and Cyrino (2003) and Meyer and Fracalossi (2005). However, no attempt was made to balance the dietary amino acid (AA) composition in relation to the fish muscle using crystalline sources of EAA (Table 2).

Sinking feeds were prepared with a laboratory extruder as described by Browdy et al. (2012). Starter pellets (2.1 $\times 8.2 \mathrm{~mm}$; diameter by length) were given to fish during acclimation and over the first 28 days of experimental culture. For the remaining culture period, fish were fed pellets of $4.0 \times 10.0 \mathrm{~mm}$. During the course of the acclimation and experimental rearing periods, fish were hand-fed twice daily, at $08.00 \mathrm{am}$ and $16.00 \mathrm{~h}$, until apparent satiation.

Fish were reared with the experimental diets for 84 days, with two additional days allowed for acclimation. At

Table 2 - Analyzed amino acid composition (g $16 \mathrm{~g} \mathrm{~N}^{-1}$ ) of experimental diets and muscle protein of a wild adult of the common snook, $C$. undecimalis

\begin{tabular}{lcccc}
\hline & \multicolumn{3}{c}{ Composition $\left(\mathrm{g} 16 \mathrm{~g} \mathrm{~N}^{-1}\right.$, dry matter basis) } \\
\cline { 2 - 4 } Amino acid & \multicolumn{3}{c}{ Experimental diet } & Muscle \\
\cline { 2 - 4 } & Basal & Poultry & SPC \\
\hline Essential & 5.97 & 6.09 & 6.05 & 5.59 \\
Arginine & 2.06 & 1.98 & 2.16 & 2.43 \\
Histidine & 3.73 & 3.89 & 3.79 & 4.35 \\
Isoleucine & 6.78 & 7.04 & 6.98 & 8.56 \\
Leucine & 12.78 & 12.17 & 13.34 & 12.41 \\
Lysine & 2.92 & 2.74 & 2.59 & 5.81 \\
Methionine & 4.05 & 4.17 & 4.31 & 4.30 \\
Phenylalanine & 3.88 & 3.65 & 3.41 & 4.66 \\
Threonine & 0.43 & 0.42 & 0.47 & 0.79 \\
Tryptophan & 4.59 & 4.84 & 4.58 & 4.98 \\
Valine & & & & \\
& & & & \\
Nonessential & 5.98 & 5.85 & 5.55 & 6.15 \\
Alanine & 8.36 & 7.67 & 8.77 & 9.85 \\
Aspartate & 0.95 & 0.94 & 0.75 & 3.35 \\
Cystine & 8.54 & 8.37 & 7.83 & 4.83 \\
Glycine & 13.37 & 13.53 & 14.30 & 15.61 \\
Glutamate & 5.35 & 5.80 & 5.27 & 3.60 \\
Proline & 3.75 & 3.68 & 3.23 & 4.15 \\
Serine & 2.80 & 2.70 & 2.63 & 3.70 \\
Tyrosine & & & & \\
\hline
\end{tabular}

SPC - soy protein concentrate. harvest, growth performance was assessed by counting and individually weighing each animal. Fish specific growth rate $\left(\mathrm{SGR}, \%\right.$ day $\left.^{-1}\right)$ was calculated by the equation: $\mathrm{SGR}=[(\ln \mathrm{Wf}-\ln \mathrm{Wi}) \div \mathrm{t}] \times 100$, in which $\mathrm{Wi}=$ fish wet body weight $(\mathrm{g})$ at stocking, $\mathrm{Wf}=$ fish wet body weight (g) at harvest, and $\mathrm{t}=$ days of culture. Daily weight gain $\left(\mathrm{DWG}, \mathrm{g} \mathrm{day}^{-1}\right)$ was determined by the formula: $\mathrm{DWG}=$ $[(\mathrm{Wf}-\mathrm{Wi}) \div \mathrm{t}]$. Feed conversion ratio $(\mathrm{FCR})$ was expressed on a dry matter basis and calculated by dividing the apparent fish feed intake by the wet fish biomass gained.

To determine the retention of dietary protein, lipid, and energy from each dietary treatment, muscle samples were collected at stocking and at harvest. Fish collection was carried out in accordance with applicable federal, state, and local laws governing animal welfare. Whole fish were pooled per tank, their muscle removed, chopped, freezedried, and then grounded to a fine powder. Nutrient and energy retention was calculated as retention $(\%)=($ final weight $\times$ final nutrient or energy content) - (initial weight $\times$ initial nutrient or energy content $) \times 100 \div$ nutrient or energy intake (NRC, 2011).

Growth performance and somatic parameters were analyzed through one-way ANOVA for completely randomized experiments. When significant differences were detected between means, they were compared pairwise with the Tukey's honestly significant difference (HSD) test. Significant level of 5\% was set for all statistical analyses. The statistical package SPSS 15.0 for Windows (SPSS Inc., Chicago, Illinois, USA) was used in all analyses. Amino acid concentration in experimental diets were analyzed by reverse-phase high-performance liquid chromatography (HPLC) following procedures described by FigueiredoSilva et al. (2015). Along with experimental diets, fish tissue samples were analyzed for dry matter (drying in a convection oven for $24 \mathrm{~h}$ at $105^{\circ} \mathrm{C}$ ), crude protein (Kjeldahl method of nitrogen estimation), and lipid (determined gravimetrically with Soxhlet extraction using acetone as the solvent), following standard methods (AOAC, 1995). Energy content was determined by combustion in a bomb calorimeter.

\section{Results}

Water quality parameters were consistent throughout the culture period $(\mathrm{P}>0.05)$. Water salinity, $\mathrm{pH}$, temperature, and dissolved oxygen reached mean (minimum - maximum) values of $32 \pm 1 \mathrm{~g} \mathrm{~L}^{-1}\left(30-34 \mathrm{~g} \mathrm{~L}^{-1}, \mathrm{n}=1080\right) ; 7.81 \pm 0.19$ $(6.7-8.1, \mathrm{n}=1073) ; 27.3 \pm 0.9^{\circ} \mathrm{C}\left(24.5-30.5^{\circ} \mathrm{C}, \mathrm{n}=1073\right)$; and 5.94 $\pm 0.21 \mathrm{mg} \mathrm{L}^{-1}(5.08-6.70, \mathrm{n}=1080)$. Similarly, water alkalinity $\left(160 \pm 15 \mathrm{mg} \mathrm{L}^{-1} \mathrm{CaCO}_{3} ; \mathrm{n}=18\right)$, total ammonia 
nitrogen $\left(0.18 \pm 0.10 \mathrm{mg} \mathrm{L}^{-1} ; \mathrm{n}=18\right)$, nitrite $\left(0.04 \pm 0.01 \mathrm{mg} \mathrm{L}^{-1}\right.$; $\mathrm{n}=12)$, and nitrate $\left(0.43 \pm 0.17 \mathrm{mg} \mathrm{L}^{-1} ; \mathrm{n}=12\right)$ did not vary significantly over the culture period $(\mathrm{P}>0.05)$.

Fish final survival reached $99.5 \pm 2.6 \%$ and was unaffected by dietary treatment $(\mathrm{P}>0.05)$. Over the rearing period, fish reached a DWG, SGR, and a final body weight ranging from 0.24 to $0.35 \mathrm{~g} \mathrm{day}^{-1}, 1.24$ to $1.57 \% \mathrm{day}^{-1}$ (Table 3), and 31.1 to $40.4 \mathrm{~g}$, respectively (Figure 1). Significant differences among dietary treatments were noted in DWG, SGR, fish yield, FCR, and final body weight $(\mathrm{P}<0.05)$ (Table 3).

Fish fed the diet containing a partial replacement of fishmeal by SPC grew slower and achieved the lowest yield and the highest FCR in comparison with fish fed the poultry $\operatorname{diet}(\mathrm{P}<0.05)$. No differences were noted in these parameters between fish fed the basal diet and those fed poultry diet $(\mathrm{P}>0.05)$. Final fish body weight was higher in fish fed poultry in comparison with those fed SPC and the basal diet (Figure 1; $\mathrm{P}<0.05$ ).

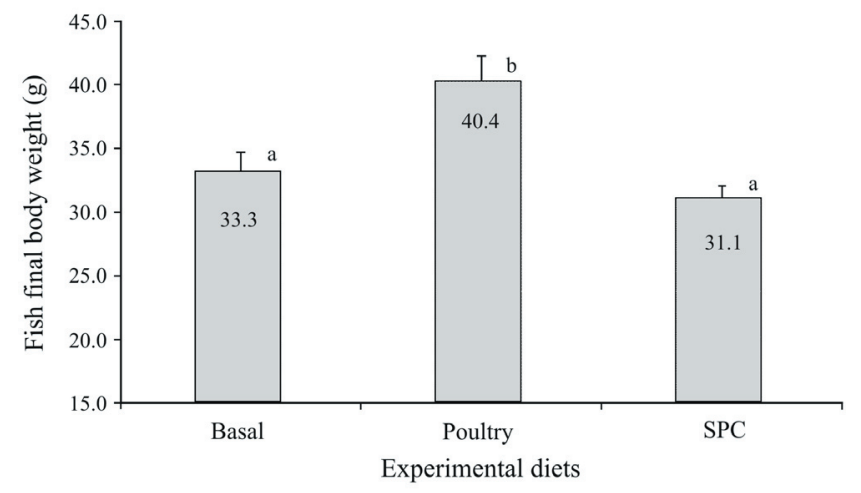

Values with different letters are significantly different according to Turkey's HSD test $(\mathrm{P}<0.05)$.

Figure 1 - Final body weight (g) of common snook, C. undecimalis $(\mathrm{n}=150)$, fed diets with partial replacement of salmon meal (basal) by poultry byproduct meal (poultry) and soy protein concentrate (SPC).
Retention of dietary protein, lipid, and energy in muscle samples of the common snook was higher in fish fed poultry (Figure 2). While retention of crude protein was in the range of 36-38\% for fish fed the basal and SPC diets, it exceeded $51 \%$ in fish fed the poultry diet. Similarly, both lipid and energy exceeded $40 \%$ retention in fish fed the poultry diet in comparison with fish fed other diets, for which values were below $36 \%$. Retention of dietary energy was the lowest among all values in fish fed the SPC diet, which may be the reason these fish also demonstrated the highest FCR values.

The essential amino acid profile relative to lysine (EAA Lys ${ }^{-1}$ ) concentration was relatively similar among experimental diets (Table 4). The overall EAA Lys ${ }^{-1}$ ratio in the muscle samples did not differ from the experimental diets $(\mathrm{P}>0.05)$. However, with the exception of $\mathrm{Arg} \mathrm{Lys}{ }^{-1}$, Phe Lys ${ }^{-1}$, and Val Lys ${ }^{-1}$, all other EAA Lys ${ }^{-1}$ ratios in the muscle samples showed differences greater than $10 \%$ for the experimental diets.

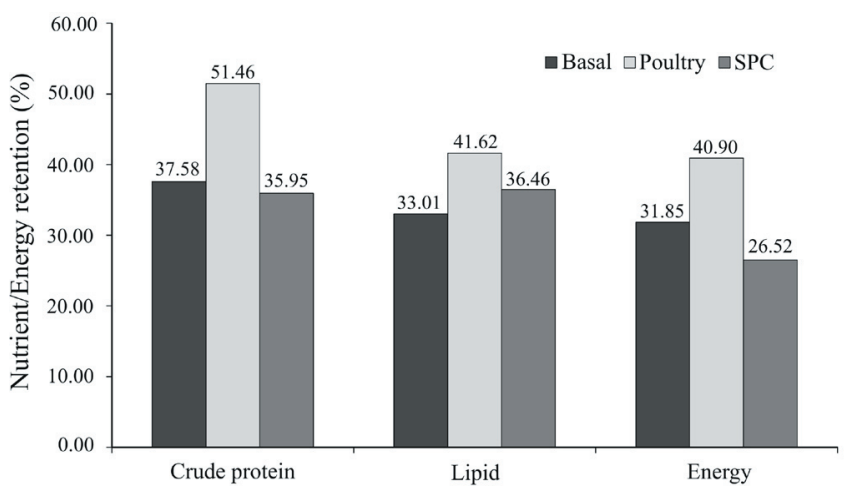

Figure 2 - Retention of dietary protein, lipid, and energy in muscle samples of the common snook, C. undecimalis, fed diets with partial replacement of salmon meal by poultry byproduct meal (poultry) and soy protein concentrate (SPC).

Table 3 - Growth performance of the common snook fed diets with progressive replacement of a salmon byproduct meal for poultry byproduct meal and soy protein concentrate $(\mathrm{SPC})^{1}$

\begin{tabular}{|c|c|c|c|c|}
\hline \multirow{2}{*}{ Performance variable } & \multicolumn{3}{|c|}{ Dietary treatment } & \multirow{2}{*}{ ANOVA P $^{2}$} \\
\hline & Basal & Poultry & $\mathrm{SPC}$ & \\
\hline Survival (\%) & $100 \pm<0.1$ & $100 \pm<0.1$ & $98 \pm 4.5$ & 0.397 \\
\hline Daily weight gain $\left(\mathrm{g} \mathrm{day}^{-1}\right)$ & $0.27 \pm 0.04 \mathrm{a}$ & $0.35 \pm 0.06 \mathrm{a}$ & $0.24 \pm 0.03 b$ & 0.007 \\
\hline Specific growth rate $\left(\%\right.$ day $\left.^{-1}\right)$ & $1.35 \pm 0.12 \mathrm{a}$ & $1.57 \pm 0.13 \mathrm{a}$ & $1.24 \pm 0.08 \mathrm{~b}$ & 0.002 \\
\hline Gained yield $\left(\mathrm{g} \mathrm{m}^{-3}\right)$ & $226 \pm 35 a$ & $297 \pm 53 a$ & $196 \pm 12 b$ & 0.003 \\
\hline Feed intake (g fish day $\left.{ }^{-1}\right)$ & $0.82 \pm 0.03$ & $0.81 \pm 0.03$ & $0.86 \pm 0.04$ & 0.052 \\
\hline Feed conversion ratio & $3.11 \pm 0.51 \mathrm{a}$ & $2.33 \pm 0.34 \mathrm{a}$ & $3.69 \pm 0.29 b$ & $<0.0001$ \\
\hline
\end{tabular}

\footnotetext{
${ }^{1}$ Fish were stocked with $10.8 \pm 0.7 \mathrm{~g}(\mathrm{n}=150)$ body weight.

${ }^{2}$ One-way ANOVA.

Common letters denote no significant difference at the $\alpha=0.05$ level by Tukey's honestly significant difference test.

Values are presented as means \pm standard deviation obtained from five rearing tanks stocked with 10 fish each.
} 
Table 4 - Balance of essential amino acids relative to lysine $\left(\mathrm{EAA} \mathrm{Lys}^{-1}\right)$, including cysteine, in experimental diets and in the muscle tissue of an adult of common snook

\begin{tabular}{lcccc}
\hline \multirow{2}{*}{ Amino acid } & \multicolumn{3}{c}{ EAA Lys $^{-1}(\%)$} & \multirow{2}{*}{ Muscle } \\
\cline { 2 - 4 } & Basal & Poultry & SPC & \\
\hline Arginine & 47 & 50 & 45 & 45 \\
Histidine & 16 & 16 & 16 & 20 \\
Isoleucine & 29 & 32 & 28 & 35 \\
Leucine & 53 & 58 & 52 & 69 \\
Methionine & 23 & 22 & 19 & 47 \\
Methionine + cysteine & 30 & 30 & 25 & 74 \\
Phenylalanine & 32 & 34 & 32 & 35 \\
Phenylalanine + threonine & 54 & 56 & 52 & 64 \\
Threonine & 30 & 30 & 26 & 38 \\
Tryptophan & 3 & 3 & 3 & 6 \\
Valine & 36 & 40 & 34 & 40 \\
\hline
\end{tabular}

SPC - soy protein concentrate.

\section{Discussion}

The present study demonstrates that juveniles of the common snook can be fed diets with poultry byproduct meal as a partial replacement of fishmeal, without deleterious growth effects. Although dietary inclusion levels of fishmeal were still high in poultry diets ( $464.2 \mathrm{~g} \mathrm{~kg}^{-1}$ of the diet), fish growth responses were equal or superior to the basal diet of $643.4 \mathrm{~g} \mathrm{~kg}^{-1}$ fishmeal. The dietary amino acid composition was not affected when poultry byproduct meal replaced $39 \%$ of the fishmeal. The fact that muscle retention of protein, lipid, and energy was better in fish fed the poultry diet, compared with those fed the basal diet, is suggestive of the enhanced digestibility and/or well-balanced nutrient composition of the poultry diet.

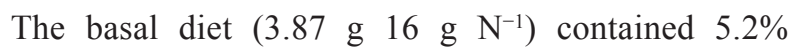
more of total sulfur amino acids (TSAA, methionine and cysteine) compared with the diet with poultry meal (3.68 g $\left.16 \mathrm{~g} \mathrm{~N}^{-1}\right)$. However, this did not contribute to a superior fish performance. Therefore, the dietary amino acid composition obtained with a combination of poultry byproduct meal (170.1 $\mathrm{g} \mathrm{kg}^{-1}$ of the diet) and salmon meal $\left(464.2 \mathrm{~g} \mathrm{~kg}^{-1}\right)$ was better utilized by fish than using salmon meal $\left(643.4 \mathrm{~g} \mathrm{~kg}^{-1}\right)$ alone.

Comparatively, the use of soy protein concentrate (SPC) as a partial replacement of fishmeal resulted in slow fish growth, although no significant effect could be attributed to feed intake levels. The inclusion of krill meal at $20.0 \mathrm{~g} \mathrm{~kg}^{-1}$ appeared to have provided sufficient attractiveness and palatability to all tested diets. The slow fish growth related to the dietary use of SPC at levels beyond $200 \mathrm{~g} \mathrm{~kg}^{-1}$ can be associated with antinutritional factors, lower digestibility of nutrients, and/or amino acid imbalances (Francis et al., 2001;
Zhou et al., 2005; Gatlin et al., 2007). Total sulfur amino acids in the SPC diet reached $3.34 \mathrm{~g} 16 \mathrm{~g} \mathrm{~N}^{-1}$, inferior than values obtained for the basal and poultry diets. The balance of essential amino acids relative to lysine (EAA Lys ${ }^{-1}$ ) in the SPC diet showed the greatest differences relative to fish muscle. The use of dietary plant protein sources have resulted in similar growth responses for other carnivorous marine fish, including the rainbow trout (Oncorhynchus mykiss; Refstie et al., 2000), cobia (Rachycentron canadum; Chou et al., 2004), Mediterranean yellowtail (Seriola dumerili, Tomás et al., 2005), and sea bream (Diplodus puntazzo, Mérida et al., 2010).

In the present study, dietary methionine varied from 1.37 to $1.52 \%$ (in a dry matter basis). This value is above methionine requirements determined for barramundi (Lates calcarifer) and other warm-water marine fish (0.8-0.9\% of the diet; NRC, 2011). The increase in dietary methionine and other amino acids was driven by an attempt to approximate dietary lysine content to fish muscle. Conversely, this resulted in dietary EAA Lys $^{-1}$ ratios below that of fish muscle. Estimations of EAA requirements in fish have also been made based on the composition of the body tissues relative to ratios of key amino acids to lysine (Glencross, 2006). However, balancing EAA Lys ${ }^{-1}$ is more effectively reached through the dietary supplementation of crystalline amino acids (Nunes et al., 2014).

In the present study, juveniles of the common snook grew at a maximum DWG of $0.35 \pm 0.06 \mathrm{~g}^{\text {day }^{-1}}$ when fed the PBM diet. This finding is consistent with other growth studies conducted with Centropomus spp., which have shown a DWG below $1 \mathrm{~g} \mathrm{day}^{-1}$ for fish of $100 \mathrm{~g}$ or less. Zarza-Meza et al. (2006a) farmed wild-caught juveniles of the common snook and the fat snook (Centropomus parallelus) together, at a 3:2 ratio in a freshwater concrete pond of $96 \mathrm{~m}^{3}$ over a 12 -month period. Juveniles with body weights of $28.9 \mathrm{~g}$ and $5.6 \mathrm{~g}$, respectively, were stocked under 2.1 animals $\mathrm{m}^{-3}$ and fed fresh tilapia (Oreochromis sp.) and ornamental fish (Poecila sp.) ad libitum. At harvest, DWG of 0.50 and $0.32 \mathrm{~g} \mathrm{day}^{-1}$ were recorded for the common and fat snook, respectively. Soligo et al. (2007) tested diets containing 463 and $572 \mathrm{~g} \mathrm{~kg}^{-1}$ fishmeal protein for $C$. undecimalis juveniles with initial body weight of $0.13 \pm 0.05 \mathrm{~g}$ under a stocking density of 1.25 fish $\mathrm{L}^{-1}$. The authors reported obtaining DWG of $0.60 \pm 0.05$ and $0.72 \pm 0.08 \mathrm{~g} \mathrm{day}^{-1}$, respectively, after 30 days. Ostini et al. (2007) farmed $C$. undecimalis juveniles with initial body weight of $32.53 \pm 6.54 \mathrm{~g}$ on a commercial feed with $400 \mathrm{~g} \mathrm{~kg}^{-1}$ protein under 20 and $40 \mathrm{fish} \mathrm{m}^{-3}$. After 160 days of rearing, the total weight gain and DWG observed were 98.6 and $87.9 \mathrm{~g}$ and 0.62 and $0.55 \mathrm{~g} \mathrm{day}^{-1}$, respectively. 
Tucker (1987) carried out a series of growth studies with the common snook. In one of the studies, the author stocked 10 fish (from wild larvae) with $13.4 \mathrm{~g}$ in three earthen ponds of $140 \mathrm{~m}^{2}$ with freshwater. Fish were fed fresh food (shrimp and scallops), but also preyed on forage fish (tilapia and mosquitofish). After 210 days, snook achieved a final body weight of $252 \mathrm{~g}$ and a DWG of $1.14 \mathrm{~g} \mathrm{day}^{-1}$. In the same study, Tucker (1987) compared the snook growth performance reared in fresh $\left(24-32^{\circ} \mathrm{C}\right.$, mean $28^{\circ} \mathrm{C}$, hardness $\left.705 \mathrm{mg} \mathrm{L}^{-1}\right)$ and in salt water $\left(25-34^{\circ} \mathrm{C}\right.$, mean $29^{\circ} \mathrm{C}, 21-33 \mathrm{~g} \mathrm{~L}^{-1}$ salinity, mean $28 \mathrm{~g} \mathrm{~L}^{-1}$ ). Fish grew from 190 to $306 \mathrm{~g}$ in freshwater and from 201 to $286 \mathrm{~g}$ in saltwater over 70 days, achieving a DWG of $0.33 \mathrm{~g} \mathrm{day}^{-1}$. In another study, Tucker (1987) evaluated six diets containing from 449 to $539 \mathrm{~g} \mathrm{~kg}^{-1}$ of crude protein and from 85 to $129 \mathrm{~g} \mathrm{~kg}^{-1}$ fat. Starting with a body weight between 15.6 and $23.9 \mathrm{~g}(17.3 \pm 2.1 \mathrm{~g})$, snook reached a final weight and DWG between 21.9-44.2 $\mathrm{g}$ (33.4 $\pm 7.2 \mathrm{~g})$ and $0.11-0.57 \mathrm{~g} \mathrm{day}^{-1}\left(0.32 \pm 0.16 \mathrm{~g} \mathrm{day}^{-1}\right)$ after 50 days of rearing, respectively.

The common snook can increase its DWG over a higher body weight range. Tucker (1987) reported DWG of 2.51, 2.74, and $4.09 \mathrm{~g} \mathrm{day}^{-1}$ for snooks that grew from 240.7 to $376.5 \mathrm{~g}, 382.2$ to $529.9 \mathrm{~g}$, and 504.4 to $725.5 \mathrm{~g}$, respectively. For 54 days, fish were fed a $516 \mathrm{~g} \mathrm{~kg}^{-1}$ crude protein diet containing $600 \mathrm{~g} \mathrm{~kg}^{-1}$ anchovy meal in combination with $135 \mathrm{~g} \mathrm{~kg}^{-1}$ poultry meal.

Disparities observed in the growth responses of C. undecimalis between studies can be attributed to differences in rearing methods, culture systems (i.e., stocking densities, green versus clear water), and fish body weight, which frequently results in hierarchical dominance and food competition. In general, there is a lack of scientifically rigorous studies on the nutritional requirements of this species, which further contributes to the variations observed in results (Tucker, 1987; Higby and Beulig, 1988; Bagley et al. 1994; Souza-Filho and Cerqueira, 2003). However, the common snook reportedly shows superior performance in comparison with other fish species of the family Centropomidae (Rubio et al., 2003; Tucker and Kennedy, 2003; ZarzaMeza et al., 2006a,b).

\section{Conclusions}

Our results indicate a greater ability of the common snook to gain weight and increase retention of nutrients when dietary protein is of animal origin. Protein from poultry byproduct meal yields a more balanced dietary amino acid composition relative to fish muscle, but possibly in excess of the species requirements.

\section{Acknowledgments}

This study was financially supported by the Brazilian Ministry of Fisheries and Aquaculture (public call CNPq/ MPA - 42/2012, grant no. 405483/2012-0). The second author acknowledges the support of a research productivity fellowship (CNPq/MCT, PQ no. 305513/2012-5). We thank Evonik Nutrition \& Care GmbH (Hanau, Germany) for conducting HPLC amino acid analyses in feed samples.

\section{References}

Alvarez-Lajonchère, L. and Ibarra-Castro, L. 2013. Aquaculture species selection method applied to marine fish in the Caribbean. Aquaculture 408-409:20-29.

AOAC - Association of Official Analytical Chemists. 1995. Official methods of analysis of Official Analytical Chemists International. 16th ed. Association of Official Analytical Chemists, Arlington, VA, USA.

Bagley, M. J.; Bentley, B. E. and Gall, G. A. E. 1994. A genetic evaluation of the influence of stocking density on the early growth of rainbow trout (Oncorhynchus mykiss). Aquaculture 121:313-326.

Boonyaratpalin, M. 1997. Nutrient requirements of marine food fish cultured in Southeast Asia. Aquaculture 151:283-313.

Browdy, C. L.; Bharadwaj, A. S.; Venero, J. A. and Nunes, A. J. P. 2012. Supplementation with 2-hydroxy-4-(methylthio) butanoic acid (HMTBa) in low fish meal diets for the white shrimp Litopenaeus vannamei. Aquaculture Nutrition 18:432-440.

Chou, R. L.; Her, B. Y.; Su, M. S.; Hwang, G.; Wu, Y. H. and Chen, H. Y. 2004. Substituting fish meal with soybean meal in diets of juvenile cobia Rachycentron canadum. Aquaculture 229:325-333.

Contreras-García, M. J.; Contreras-Sánchez, W. M.; Hernádez-Vidal, U. and Mcdonal-Vera, A. 2015. Induced spawning of the common snook (Centropomus undecimalis) in captivity using GnRH-a implants. Ecosistemas y Recursos Agropecuarios 2:357-362.

FAO - Food and Agriculture Organization of the United Nations. 2014. The State of World Fisheries and Aquaculture 2014. Food and Agriculture Organization of the United Nations, Rome.

Ferraz, E. M. and Cerqueira, V. R. 2010. Influência da temperatura na maturação gonadal de machos do robalo-flecha, Centropomus undecimalis. Boletim do Instituto de Pesca 36:73-83.

Figueiredo-Silva, C.; Lemme, A.; Sangsue, D. and Kiriratnikom, S. 2015. Effect of DL-methionine supplementation on the success of almost total replacement of fish meal with soybean meal in diets for hybrid tilapia (Oreochromis niloticus $\times$ Oreochromis mossambicus). Aquaculture Nutrition 21:234-241.

Francis, G.; Makkar, H. P. S. and Becker, K. 2001. Antinutritional factors present in plant-derived alternate fish feed ingredients and their effects in fish. Aquaculture 199:197-227.

Gatlin, D. M.; Barrows, F. T.; Brown, P.; Dabrowski, K.,; Gaylord, T. G.; Hardy, R. W.; Herman, E.; Hu, G.; Krogdahl, A.; Nelson, R.; Overturf, K.; Rust, M.; Sealey, W.; Skonberg, D.; Stone, E. J. S. D.; Wilson, R. and Wurtel, E. 2007. Expanding the utilization of sustainable plant products in aquafeeds: a review. Aquaculture Research 38:551-579.

Glencross, B. 2006. The nutritional management of barramundi, Lates calcarifer - a review. Aquaculture Nutrition 12:291-309.

Gracia-López, V.; García-Galano, T.; Gaxiola-Cortés, G. and Pacheco-Campos, J. 2003. Effects of dietary protein level and commercial feeds on growth and feeding of juvenile common 
snook, Centropomus undecimalis (Bloch, 1792). Ciencias Marinas 29:585-594.

Gracia-López, V.; Rosas-Vázquez, C. and Brito-Pérez, R. 2006. Effects of salinity on physiological conditions in juvenile common snook Centropomus undecimalis. Comparative Biochemistry and Physiology, Part A, Molecular \& Integrative Physiology 145:340-345.

Higby, M. and Beulig, A. 1988. Effects of stocking density and food quantity on growth of young snook, Centropomus undecimalis, in aquaria. Florida Scientist 51:161-171.

Ibarra-Castro, L.; Alvarez-Lajonchère, L.; Rosas, C.; PalominoAlbarrán, I. G.; Holt, G. J. and Sanchez-Zamora, A. 2011. GnRHainduced spawning with natural fertilization and pilot-scale juvenile mass production of common snook, Centropomus undecimalis (Bloch, 1792). Aquaculture 319:479-483.

Mérida, S. N.; Tomás-Vidal, A.; Martínez-Llorens, S. and Cerda, M. J. 2010. Sunflower meal as a partial substitute in juvenile sharpsnout sea bream (Diplodus puntazzo) diets: amino acid retention, gut and liver histology. Aquaculture 298:275-281.

Meyer, G. and Fracalossi, D. M. 2005. Estimation of jundiá (Rhamdia quelen) dietary amino acid requirements based on muscle amino acid composition. Scientia Agricola 62:401-405.

Muller, R. G. and Taylor, R. G. 2012. The 2012 stock assessment update of common snook, Centropomus undecimalis. Fish and Wildlife Conservation Commission, Florida Marine Research Institute, St. Petersburg, Florida.

NRC - National Research Council. 2011. Nutrient requirements of fish and shrimp. National Academy Press, Washington, DC, USA.

Neidig, C. L.; Skapura, D. P.; Grier, H. J. and Dennis, C. W. 2000. Techniques for spawning common snook: broodstock handling, oocyte staging, and egg quality. North American Journal of Aquaculture 62:103-113.

Nunes, A. J. P.; Sá, M. V. C.; Browdy, C. L. and Vázquez-Añón, M. 2014. Practical supplementation of shrimp and fish feeds with crystalline amino acids. Aquaculture 431:20-27.

Ostini, S.; Oliveira, I. R; Serralheiro, P. C. S. and Sanches, E. G. 2007. Criação do robalo-peva (Centropomus parallelus) submetido a diferentes densidades de estocagem. Revista Brasileira de Saúde e Produção Animal 8:250-257.

Pérez-Pinzón, M. A. and Lutz, P. 1991. Activity related cost of osmoregulation in the juvenile snook, Centropomus undecimalis. Bulletin of Marine Sciences 48:58-66.

Portz, L. and Cyrino, J. E. P. 2003. Comparison of the amino acid contents of roe, whole body and muscle tissue and their A/E ratios for largemouth bass Micropterus salmoides. Aquaculture Research 34:585-592.

Refstie, S.; Korsøen, O. J.; Storebakken, T.; Baeverfjord, G.; Lein, I. and Roem, A. J. 2000. Differing nutritional responses to dietary soybean meal in rainbow trout (Oncorhynchus mykiss) and Atlantic salmon (Salmo salar). Aquaculture 190:49-63.

Rhody, N. R.; Nassif, N. A. and Main, K. L. 2010. Effects of salinity on growth and survival of common snook Centropomus undecimalis (Bloch, 1792) larvae. Aquaculture Research 41:e357-e360.

Rhody, N. R.; Puchulutegui, C.; Taggart, J. B.; Main, K. L. and Migaud, H. 2014. Parental contribution and spawning performance in captive common snook Centropomus undecimalis broodstock. Aquaculture 432:144-153.

Rivas, L. R. 1986. Systematic review of the perciform fishes of the genus Centropomus. Copeia 3:579-611.
Rubio, E. A.; Loaiza, J. H. and Moreno, C. J. 2003. Observaciones sobre el crecimiento de dos especies de robalos (Centropomus viridis y Centropomus armatus) en jaulas flotantes en zonas estuarinas de la Bahía de Buenaventura. p.1-7. In: Memorias del IV Seminario Internacional de Acuicultura, Bogotá, Colombia.

Salze, G., McLean, E.; Battle, P. R.; Schwarz, M. H. and Craig, S. R. 2010. Use of soy protein concentrate and novel ingredients in the total elimination of fish meal and fish oil in diets for juvenile cobia, Rachycentron canadum. Aquaculture 298:294-299.

Sánchez-Zamora, A.; Gomez, L. M.; Garcia, T.; Suárez, J.; Rosas, C. and Gaxiola, G. 2002. Maturation and spawning of common snook: first experiences in Southeast Mexico. World Aquaculture 33:62-65.

Soligo, T. A.; Souza, R. M. and Cerqueira, V. R. 2007. Comparação de dietas no desmame do robalo-flecha, Centropomus undecimalis. p.27-36. In: Soligo, T. A. Primeiras experiências com a reprodução, larvicultura e desmame do robalo-flecha, Centropomus undecimalis no Brasil. Dissertação (M.Sc.). Universidade Federal de Santa Catarina, Florianópolis.

Soligo, T. A.; Garcia, A. S. and Cerqueira, V. R. 2011. Weaning of the common snook (Centropomus undecimalis) early juveniles reared in laboratory using commercial and experimental diets. Boletim do Instituto de Pesca 37:367-374.

Souza-Filho, J. J. and Cerqueira V. R. 2003. Influência da densidade de estocagem no cultivo de juvenis de robalo-flecha mantidos em laboratório. Pesquisa Agropecuária Brasileira 38:1317-1322.

Tomás, A.; Gándara, F.; García-Gomez, A.; Pérez, L. and Jover, M. 2005. Utilization of soybean meal as an alternative protein source in the Mediterranean yellowtail, Seriola dumerili. Aquaculture Nutrition 11:333-340.

Tsuzuki, M. Y.; Sugai, J. K.; Maciel, J. C.; Francisco, C. J. and Cerqueira, V. R. 2007. Survival, growth and digestive enzyme activity of juveniles of the fat snook (Centropomus parallelus) reared at different salinities. Aquaculture 271:319-325.

Tucker, J. W. and Kennedy Jr., S. B. 2003. Comparison of some developmental, nutritional, behavioural, and health factors relevant to stocking of striped mullet (Mugilidae), sheepshead (Sparidae), common snook (Centropomidae), and Nassau groupers (Serranidae). p.191-194. In: Ecology of aquaculture species and enhancement of stocks. Kakamura, Y.; McVey, J. P.; Leber, K.; Neidig, C.; Fox, S. and Churchill, K., eds. Proceedings of the Thirtieth U.S. - Japan Meeting on Aquaculture. UJNR Technical Report No. 30. Sarasota, FL, USA.

Tucker, J. W. 1987. Snook and tarpon snook culture and preliminary evaluation for commercial farming. The Progressive Fish Culturist 49:49-57.

Zarza-Meza, E. A.; Berruecos-Villalobos, J. M.; Vásquez-Peláez, C. and Álvarez-Torres, P. 2006a. Experimental culture of common snook Centropomus undecimalis (Bloch, 1792) and fat snook Centropomus parallelus (Poey, 1860) (Perciformes: Centropomidae) in freshwater concrete pond. Veterinaria México 37:327-329.

Zarza-Meza, E. A.; Berruecos-Villalobos, J. M.; Vásquez-Peláez, C. and Álvarez-Torres, P. C. 2006b. Experimental culture of snook Centropomus undecimalis and chucumite Centropomus parallelus (Perciformes: Centropomidae) in artisanal earthen ponds. Ciencias Marinas 32:219-227.

Zhou, Q. C.; Mai, K-S.; Tan, B-P. and Liu, Y-J. 2005. Partial replacement of fishmeal by soybean meal in diets for juvenile cobia (Rachycentron canadum). Aquaculture Nutrition 11:175-182. 